\title{
Political Parties in Kosovo, Organizational Structure and Their Internal Democracy
}

\author{
Dr. Sci. Veton Zejnullahi
}

\begin{abstract}
The collapse of communism in the former Eastern bloc, which was followed by the establishment of democracies popular and holding free elections to the parliaments of the countries concerned had its impact in Kosovo, which although occupied accepted among first democracy in the former Yugoslavia, which was followed by the creation of political parties at that time. The role of political parties in the years of occupation there was a genuine character of party activity as a result of the occupation, because the main word on Kosovo was Serbian government, installed after violent suppression of Kosovo's autonomy in 1989. Political parties in general It served as a national movement, some of which joined the Kosovo Albanians by articulating their demands for freedom and independence. This included organizing parties in Kosovo and the Albanian parties in other areas in the former Yugoslavia was organized by the Coordination Council of Albanian Parties. End of the war in 1999 brought a completely new situation, changing political scene with the formation of more political parties, as well as providing more opportunities for a better organization of the political scene. Some of the political parties no longer exist, while others have a very small number of members. The formation of new parties expected profiling of political scene, however, serves only their declarative they are right or left, in most cases a proper profiling has not happened yet. Political parties in Kosovo even after so many years of activity apparently still in the phase of consolidation but also in search of their identity.
\end{abstract}

Keywords: Kosovo , political parties , internal democracy , occupation

\section{Introduction}

A political party in Kosovo originates since the early nineties of the last century, more precisely after the collapse of the party system of government, led by the Communist Party. Knowing that in those years, Kosovo was under severe apartheid, and under occupation classic, certainly cannot speak as to the normal functioning of political parties, much less internal democracy subjects then political, because the activity was almost other semi, since as members also hounded and jailed leaders from the Serbian government in Kosovo installed. Known as the "Kosovo Option", which in itself includes all parties of that time, they managed to hold twice conditions parliamentary and presidential elections in 1992 and 1998 where he was elected Parliament and President of the Republic, bodies which they never made it constituted as a result of repressive measures imposed by the Serbian authorities. Democratic League of Kosovo party was first formed which was followed by the other parties as Peasant Party, the Albanian Christian Democratic Party, the Parliamentary Party and some other smaller parties. We must emphasize illegal entities that operated underground from which later formed the KLA, the Kosovo National Movement and the National Movement for the Liberation of Kosovo.

In such conditions we could not occupation for internal party democracy, because every decision taken by the party chairman. Although held an internal election process, it was all very formal and serves propaganda purposes than genuine internal democracy.

But after the war in 1999, in Kosovo, and the creation of new circumstances were formed many political parties thus enriching the political scene, while in terms of internal organization of particular internal democracy is still a lot to be desired . Political parties are still operating under the old system with a retention assembly or congress, in which the chairman shall propose a list of party organs and which is approved by acclamation by the delegates present. Formally opened an internal election process, but that is not supervised and decisions are prepared and almost become the choice of people loyal to the party leader. Even in other parties the situation is almost identical, because long before the elections, it is known who will be chairman of the party and the team close to him, and in all cases the party chairman has no opposition candidates in case of election, or even if one candidate, more formal candidacy, saying better than for show and meet a point required by statute. 


\section{Political organization in Kosovo}

Political organization in Kosovo as in any other country is regulated by law. Kosovo is a pluralist parliamentary system of organization and political activity. Political parties in Kosovo operate under Regulation number 01/2013 on the registration and operation of political parties ${ }^{1}$.

The political scene in Kosovo is characterized by parties to the ideology declared as the right where you can list the PDK, LDK, AAK, left-wing parties as VV , party center-right and center-left , then party religious character as Albanian Christian Democratic Party - PSHDK, which show the values of the Christian Democratic Party and Justice- PD , which discloses Islamic values and national minority parties that aim are the protection and representation of minorities in parliament . Otherwise, according to the register in Kosovo currently operate 63 political parties be they political party, movement or election list².

All non-Serb minority parties in parliament have their parliamentary group "Six plus" through which participate in government with a ministerial post and some other lower positions. While Serb minority is organized by some parties and a list called "Serbian List" which is led by the Serbian government and the conviction that there is no action taken without prior consultation with Belgrade officials. Otherwise the government represented by three ministerial posts and several government positions lower under the country's constitution and comprehensive plan of President Ahtisaari. Regarding the organizational structure and internal democracy is about the same as other political parties.

It is clear that the political scene is not yet profiled and related coalitions for narrow interests of power and not because the program. Even the voting is still done based on non-program leader of the political party and still presents family voting.

Political parties in Kosovo have not yet been organized elections within the party that will really touch a step forward in the organization as well as in political emancipation but also in terms of internal democracy. With the exception of Vetevendosje Movement, which tried to take a bold step, but unfortunately was only a step, nothing more.

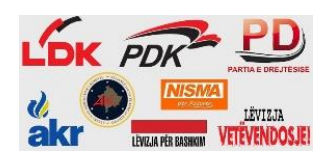

Photo.Logos of some political parties ${ }^{3}$

\section{The organizational structure of political parties}

Political parties in Kosovo have almost similar organizational structure, the parties emerged in the former communist bloc in Eastern Europe . In order to include as many people in the structure, including remote mountain areas, build party structures are such that no one remains outside the organizational structure. The names of the structure are different and distinct from the parties as asset, section, paragraph, center etc, but basically the function is the same. Levels of organization usually look like this:

Asset - session- lower unit of the organization and consists of Assembly and Board

Sub-branch - points -content the assembly and the presidency of the sub - paragraph

Branch - center - consists of assembly and board of branch - center.

Party Assembly - delegates from all branches, including branches of the Diasporas elects the Board and President of the party

Governing Council or General - elect party leadership; The national party; The party leader; Women's Forum; Youth Forum

\footnotetext{
$1 \mathrm{http}: / /$ politike.al/wp-content/uploads/2016/03/Rregullore-per-regjistrimin-e-partive-politike-Kosove.pdf

2 http://www.kqz-ks.org/Uploads/Documents/15-9- 2013\%20Regjistrti\%20i\%20partive\%20politike\%20ne\%20Kosove_dxjexszvhx.pdf

${ }^{3} \mathrm{http}: / / w w w . a l b i n f o . c h / k o s o v e-p a r t i t e-p o l i t i k e-p a-d e m o k r a c i-t e-b r e n d s h m e /$
} 
During elections the electoral process by proposing delegates for central assembly, and at all levels of the organization. After all proposals voted branch delegates who represent the central assembly.

On the other hand the party's central organization is almost the same to all parties, or just changes the name of the body which plays the same role. In central assembly voted for the Governing Council or General of the party, who is obliged to elect party leadership. According to statutory regulation Assembly elects the Chairman of the party.

But what happens with the election of the leadership directly affects internal democracy, because the party president is empowered to propose that the list of members of the presidency are here this straight cut this right to assembly.

Also every political party have formed organizations of women and that of young people, in the form of special forums , which meant they carry values that disclosure of these two categories more vital to society .

Besides AAK, through statute has regulated explicitly the representation of women and youth through quotas in decision making structures of the party ${ }^{1}$, in terms of other parties, there is a general conviction that these forums more are as decoration party than to have any impact on the party's policies, not having representation quotas set. All we have managed to "win " is what the respective presidents have automatically secure place in central presidency, so the structure representation is usually over $90 \%$ of men in the leadership as well as in other governing bodies of the party.

\section{Internal democracy in political parties in Kosovo}

When we read the programs of political parties and their statutes, an assumption that we are dealing with subjects that in most cases, except for the acronym "democratic", actually have internal democracy, and everything done according to statutory rates.

But when we see actions that occur during daily activity, especially on the eve of election campaigns, the acronym "democratic" loses its meaning. In most cases applies the principle, where the mayor party's own party, because contrary to any norm statutory him above his party and decides on its behalf, especially during the accession of new members during electoral campaigns in many cases members newcomer also appointed deputy chairman of the party, during the press conference specially convened for this activity by violating the party statute which clearly specifies how elected deputy party, or any other function that has to do with the presidency.

This phenomenon is present with all parties without exception and serves as proof of how the party is strengthened. In most cases, the newcomers have just taken the post of deputy, left acting as an independent in parliament, because their condition is included in the list for deputy or ministerial posts, whether minister or deputy minister.

In some examples to see how it works in real internal democracy of the main political parties.

Since the establishment of the first political parties in Kosovo, forms of organizing elections within the party has remained the same, marking a standstill in relation to the region and comparison with established democratic countries as doable . In almost all cases contested assembly election - Congress political parties in all Albanian political geography.

In this paper we will focus on some of the major political parties that are simultaneously parliamentary party, and more specifically -PDK Democratic Party of Kosovo, the Democratic League of Kosovo - LDK, Vetevendosje Movement - LVV, and see how they work especially as they respect internal democracy, based on conventions - assemblies their party conventions . To gain a clearer picture as to make a comparison with the main political parties operating in the Republic of Albania, namely three main parties, the Socialist Party - PS -PD Democratic Party and the Socialist Movement for Integration, LSI .

Regarding the electoral conventions of political parties in Kosovo, excluding assembly of LDK, known as "Assembly chair" during which ran two candidates from two sets to take over the party, but that escalated into violence between the two groups rival.

\footnotetext{
1 http://www.aak-ks.org/?id=18
} 
The outcome was fatal for the group as it usually occurs won the Albanian political spectrum, entirely removed; leaving the other group outside the party structures that resulted in the formation of another party, the Democratic League of Dardania - LDD.

This division also contributed to the division of the electorate and also divided into two groups, once the first party in the country's general elections was defeated by second-ranked political entity.

So rather than this moment be used for further deepening of internal democracy of the party, through the legalization of factions within the party as political parties in countries with democracy more advanced, there was quite the opposite and the party was closed on itself by guided by a narrow group of people that led to inevitable defeat in national election.

There is no party that has installed the principle of one member one vote, where election commissions will rise and will vote secretly on ballot boxes, which will be the result of an election campaign in party and numerous meetings with party membership. It is worth mentioning that the ethnic Albanian lands the first to have applied the system one member one vote, is the Socialist Movement for Integration in the Republic of Albania, which was later followed by the Socialist Party, and lately also from the Democratic Party, after losing she suffered in national elections. But, unfortunately, these elections were contested by candidates for President of the Party, as happened in the case of DP raising contentious issues in the election process in the Democratic Party. So we are dealing with phenomena that select the outgoing President of its successor, and prepared the same field that also solved. This is explained by the fact that the outgoing president still wants to maintain influence in the party.

Contests were recently in elections organized by the Socialist Party to hold a referendum on the election of the party chairman, which was impossible with a campaign equal to good arguments, members of the Socialist Party, and as usually happens, the parties Albanian land he lost the party chairmanship after the end of the congress. We must mention that the perpetrator list compiled for the party chairman and the same has proposed and is endorsed by the party.

Tradition of denial of internal democracy joined the Democratic Party of Kosovo - PDK, which recent convention attended the same operations as other political parties regarding the election of the party leader who was elected by acclamation by delegates assembly. Also a list for party leadership which was proposed by the chairman was adopted without objection. At the last congress delegates it is interesting that with their vote have determined the party's ideological character by declaring party as right, though this should not be party oriented programming decision, not assembly. The same operations were done again for president of their party convention VII PDK, in which there were no opposition candidates and there was no secret ballot, but the mayor was elected by open ballot which is inconsistent with the Party Statute.

Contestations made in the last Assembly election the Democratic League of Kosovo - LDK for a point in the statute requires that a candidate for the post of party president needed the signatures of $51 \%$ of the delegates to the convention, which actually prevented running Vjosa Osmani fact logically and mathematically only one candidate can reach this number, which in this case is the chairman of the current party 's re-election which was not voted into the assembly after being elected by acclamation by eliminating the democratic procedure of election of the President through secret ballot determined by the statute. As in the case with other parties, LDK was not immune and did the same, approving the list of members of the leadership which the proposed chairman of the party at which inevitably lack the name Vjosa Osmani and several supporters of her, remaining outside the party leadership.

Vetevendosje Movement is the only person who tried through ballot boxes organizes internal elections by inviting the membership to vote on the day of voting, but it is the general impression that the current chairman of the selected founder of the Movement, which is explained by the fact of conservation the impact on the Movement. VV is the only entity which puts in place a disciplinary commission ${ }^{1}$ which in some cases has taken a decision to exclude members. Committees such de - jure remove those members who have run afoul of the charter party but de - facto eliminate political dissent in a political party, although in VV there is a group called " faction plus " consisting precisely of members excluded from the disciplinary commission.

\footnotetext{
1 http://www.vetevendosje.org/wp-content/uploads/2013/09/Statuti_i_Levizjes_VETEVENDOSJE_mars_2012.pdf 


\section{Conclusions}

Political parties step up their activities normally in the eve of the election campaign at any level whether elections where new arrivals start bypassing party for democracy and internal rules for party chairman makes their cooptation without no preliminary proceedings and outside the party apparatus makes appointment to important positions in the party and appointment to a senior ministerial post or choice for deputy in Parliament. Usually targeted by these flows are journalists and members of civil society who are critics of the party and thus vanish even as opposition voices are few in society. Independent intellectuals were targeted political parties, but the practice has shown that in these cases, this action served more as decoration than supposedly intellectuals are politically engaged than he has had any positive impact on their engagement.

Compiling lists for national elections and the candidates for mayor formally made through branches of political parties, but the last word usually is the party chairman who often defy the opinion of branches and list which it also approves the list becomes official party to participate in elections .

Never in Kosovo has no political party internal election process step through its branches with two or more candidates who will be running the first election in the party programs and then in municipal elections for mayor.

Participation of women in political life is very small and is usually organized through the forum of women who like the forum of youth have no impact on party politics and simply serve only as numbers and to meet obligations arising from statute . The $30 \%$ who serves on the participation of women in Parliament and in Municipal Councils does not apply to their representation in the party and as a result of all municipalities is the only female president of the municipality and two women ministers in the Government of Kosovo. Therefore, women's organizations and youth it rather than be the partner organizations with political parties that operate them usually are dependent on them and this affects their activity is limited to party frameworks.

Knowing that internal democracy means participation of citizens in politics and internal party through which I express their concerns and being organized in various working groups that practice there are no political parties in Kosovo comes into disinterest of citizens especially the middle class to join the party, so no political party in Kosovo do not know the exact number of its members and usually confused by the mixed here with the number of voters or supporters.

Another characteristic is that all parties in Kosovo are therefore belonging to a national group lacking national minorities when entering the Albanian parties or even the opposite. This is a precedent for countries in the region are frequent cases where political parties have more character represented all citizens and ethnic groups.

Women's organizations and youth it rather than be the partner organizations with political parties that operate them usually are dependent on them and this affects their activity is limited to party frameworks.

Disciplinary Commissions although serving in principle for maintaining statutory violations at a party although de - jure remove those members who have run afoul of the statute of the party, there is a general conviction that de - facto eliminate political dissent in a political entity.

\section{Bibliography}

[1] Daniel-Louis Seiler, Partitë politike, UET Press Tiranë

[2] Wilhelm Hofmeister, Karsten Grabow, Partitë politike- funksioni dhe organizimi në shoqëritë demokratike

[3] Demokracia e brendshme partiake në Kosovë, Qendra për hulumtim dhe ndërtim të politikave

[4] Mentor Agani, Gent Gjikolli, Albert Krasniqi, Blerim Murtezi, Violeta Haxholli , Sistemi zgjedhor dhe partiak në Kosovë, perspektiva e zhvillimit të demokracisë brenda partiake

[5] http://www.aak-ks.org/?id=18

[6] http://www.albinfo.ch/kosove-partite-politike-pa-demokraci-te-brendshme/

[7] http://www.kqz-ks.org/Uploads/Documents/15-9-

2013\%20Regjistrti\%20i\%20partive\%20politike\%20ne\%20Kosove_dxjexszvhx.pdf

[8] http://politike.al/wp-content/uploads/2016/03/Rregullore-per-regjistrimin-e-partive-politike-Kosove.pdf

[9] http://www.vetevendosje.org/wp-

content/uploads/2013/09/Statuti_i_Levizjes_VETEVENDOSJE_mars_2012.pdf 